\title{
Left ventricular mass in coronary artery disease without hypertension Haemodynamic and angiocardiographic study
}

\author{
H. J. Pech, J. Witte, R. Romaniuk, R. A. Parsi, and W. Porstmann \\ From I Medical Clinic and Diagnostic Department of Cardiovascular Disease, Humbold 1 University \\ (Charité Hospital), Berlin, G.D.R.
}

Left heart catheterization, quantitative angiocardiography, and selective coronary angiography were undertaken in 64 patients with angina pectoris. The patients were subdivided into four groups according to severity of coronary arteriosclerosis. The mass of the left ventricle was significantly increased in patients with coronary artery disease as compared to those with normal coronary arteriograms.

No correlation could be found between left ventricular mass and left ventricular stroke work. Significant correlations were observed with end-diastolic tension and pressure, and a lesser correlation with end-diastolic volume, in patients with advanced coronary arteriosclerosis. Higher end-diastolic wall tension represents compensation by the Frank-Starling mechanism to maintain adequate stroke work. Increased left ventricular mass seems to be the result of and to compensate for, a higher wall tension.

Post-mortem investigations in certain cases of coronary arteriosclerosis or myocardial infarction (without hypertension) have revealed hypertrophy of the left ventricle (Busch, 1953; Ellis et al., 1962; McCain, Kline, and Gilson, I950; Murata et al., 1972; Zaino and Tabor, 1963). While such hypertrophy is believed to be a compensatory process, its actual pathogenetic mechanism has not yet been elucidated (Badeer, 1971, 1972). Necropsy alone is not sufficient for elucidation and must, therefore, be complemented by additional in vivo haemodynamic and metabolic studies.

The advent of coronary angiography and left ventriculography has permitted in vivo assessment of the coronary vessels and of left ventricular dimensions and mass (Rackley et al., 1970).

This study presents a comparison between results obtained by haemodynamic and angiocardiographic measurement and those recorded by coronary angiography from patients with chronic ischaemic heart disease.

\section{Patients and methods}

The findings referred to in this paper were obtained from 64 patients ( $6 \mathrm{I}$ male, 3 female), aged between 32 and 62 , who had undergone diagnostic left heart catheterization,

Received 28 August 1973. including angiocardiography, and selective coronary arteriography for investigation of chest pain (Table $r$ ). (Patients with arrhythmia, blood pressure in excess of $140 \mathrm{mmHg}$ systolic, primary cardiomyopathy, aortic valve disease, and aneurysm of the left ventricle were excluded from this study.)

The patients were subdivided into four groups, with reference to morphologic results obtained by coronary angiography:

Group O: Normal coronary arteriogram.

Group I: Plaques or stenosis.

Group II: Stenosis of a major vessel with evidence of haemodynamic insufficiency (retrograde filling of the post-stenotic part of the vessel by collateral circulation, considerably delayed filling of the post-stenotic part of the left anterior descending or circumflex branch compared with the parallel vessel, or asynchrony in the left ventriculogram, as described by Herman et al. (1957).

Group III: Occlusion of a major vessel (main right coronary artery, left anterior descending branch, left circumflex branch).

Catheterization was performed after moderate sedation and under local anaesthesia. After retrograde catheterization from the femoral artery, 40 to $60 \mathrm{ml}$ 'Visotrast $370^{\prime 1}$ were injected continuously or intermittently into 1 VEB Fahlberg List, Magdeburg. 
TABLE I Synopsis of data from 64 patients with angina pectoris

\begin{tabular}{|c|c|c|c|c|c|c|c|c|c|c|c|}
\hline Group & No. & $\begin{array}{l}\text { Sex } \\
M\end{array}$ & $F$ & $\begin{array}{l}\text { Age } \\
\text { (yr) }\end{array}$ & $\begin{array}{l}L V \text { mass } \\
\left(g / m^{2}\right)\end{array}$ & $\begin{array}{l}L V \text { end- } \\
\text { diastolic } \\
\text { vol. } \\
\left(\mathrm{ml} / \mathrm{m}^{2}\right)\end{array}$ & $\begin{array}{l}\text { LVend- } \\
\text { diastolic } \\
\text { pressure } \\
(m m H g)\end{array}$ & $\begin{array}{l}\text { LV end- } \\
\text { diastolic } \\
\text { tension } \\
(\text { dyne } \mid \\
\left.\mathrm{cm} \cdot \mathrm{IO}^{3}\right)\end{array}$ & $\begin{array}{l}\text { Tension } \\
\text { mass } \\
\text { index } \\
(\text { dyne } \mid \\
\left.\mathrm{cm} / \mathrm{g} \cdot \mathrm{IO}^{-2}\right)\end{array}$ & $\begin{array}{l}L V \text { stroke } \\
\text { work } \\
\text { index } \\
(\mathrm{kpm} / \\
\left.\min / \mathrm{m}^{2}\right)\end{array}$ & $\begin{array}{l}\text { Work mass } \\
\text { index } \\
(\mathrm{g} \mathrm{m} / \mathrm{min} / \mathrm{g})\end{array}$ \\
\hline $\mathbf{O}$ & 15 & 13 & 2 & $\begin{array}{l}4 I \cdot 0 \pm 9 \cdot 0 \\
(25-6 I)\end{array}$ & $\begin{array}{c}93 \pm 16.5 \\
(70-134)\end{array}$ & $\begin{array}{l}80 \pm 13 \cdot 4 \\
(56-97)\end{array}$ & $\begin{array}{l}7 \cdot 5 \pm 3 \cdot 2 \\
(6-9)\end{array}$ & $\begin{array}{l}24 \pm 4 \cdot 6 \\
(16-3 I)\end{array}$ & $\begin{array}{l}24 \pm 6 \cdot 2 \\
(13-38)\end{array}$ & $\begin{array}{l}5 \cdot 7 \pm I \cdot 8 \\
(3 \cdot I-8 \cdot 9)\end{array}$ & $\begin{array}{l}56 \pm 18 \cdot 4 \\
(27-80)\end{array}$ \\
\hline I & I3 & 13 & - & $\begin{array}{l}49 \cdot 2 \pm 7 \cdot 3 \\
(42-6 I)\end{array}$ & $\begin{array}{l}107 \pm 20.6 \\
(77-140)\end{array}$ & $\begin{array}{c}94 \pm I 5 \cdot 7 \\
\left(75^{-1} 19\right)\end{array}$ & $\begin{array}{l}7 \cdot 4 \pm I \cdot 6 \\
(5-9)\end{array}$ & $\begin{array}{l}25 \pm 5 \cdot 6 \\
(16-31)\end{array}$ & $\begin{array}{l}23 \pm 5 \cdot 6 \\
(14-33)\end{array}$ & $\begin{array}{l}5 \cdot 5 \pm 1 \cdot 6 \\
(3 \cdot 1-7 \cdot 7)\end{array}$ & $\begin{array}{l}52 \pm 13.6 \\
(34-72)\end{array}$ \\
\hline II & I4 & 14 & - & $\begin{array}{l}44 \cdot 9 \pm 9 \cdot 1 \\
(32-62)\end{array}$ & $\begin{array}{l}127 \pm 30 \cdot 3 \\
(86-204)\end{array}$ & $\begin{array}{l}88 \pm 27 \cdot 0 \\
(40-130)\end{array}$ & $\begin{array}{l}9 \cdot 9 \pm 3 \cdot 2 \\
(5-14)\end{array}$ & $\begin{array}{l}3 I \pm I I \cdot 9 \\
(I 4-45)\end{array}$ & $\begin{array}{l}24 \pm 7 \cdot 5 \\
(15-36)\end{array}$ & $\begin{array}{l}5 \cdot I \pm I \cdot 8 \\
(2 \cdot 4-7 \cdot 8)\end{array}$ & $\begin{array}{l}44 \pm 19.0 \\
(17-88)\end{array}$ \\
\hline III & 22 & 21 & I & $\begin{array}{l}49 \cdot 1 \pm 6 \cdot 7 \\
(38-62)\end{array}$ & $\begin{array}{l}125 \pm 37 \cdot 3 \\
(60-214)\end{array}$ & $\begin{array}{l}\text { I I } 3 \pm 43 \cdot \text { I } \\
(44-244)\end{array}$ & $\begin{array}{l}12 \cdot 7 \pm 7 \cdot 7 \\
(5-38)\end{array}$ & $\begin{array}{l}43 \pm 32 \cdot 5 \\
(15-165)\end{array}$ & $\begin{array}{l}34 \pm 17 \cdot 1 \\
(16-77)\end{array}$ & $\begin{array}{l}3 \cdot 7 \pm 1 \cdot 6 \\
(1 \cdot 0-7 \cdot 2)\end{array}$ & $\begin{array}{c}34 \pm 18 \cdot 9 \\
(5-76)\end{array}$ \\
\hline
\end{tabular}

the left ventricle, using an automatic high-pressure injector. Cine ventriculograms were made at 50 frames $/ \mathrm{sec}$ in anteroposterior and lateral projections, using a 'cine pulse unit' and an Arriflex 35-mm camera.

Left ventricular pressure was recorded by means of a P23 Statham pressure transducer just before injection of contrast medium, and all pressures were related to a zero level $5 \mathrm{~cm}$ below the sternal angle.

Ventriculography was followed by selective coronary arteriography by the technique of Judkins (I968).

The cine film was viewed on a projector and a cardiac cycle selected for volume and mass determination. Calculations were performed at end-diastolic ( $Q$ wave of 1 Philips, Einthoven. simultaneously recorded electrocardiogram) and endsystolic (end of $T$ wave) phases. The outline of the ventricle was traced from these projections. Wall thickness of the left ventricle was measured from enddiastolic films in the anteroposterior projection approximately half-way between the apex and the aortic valve (Fig. I).

Evaluation of recordings that showed extrasystoles during contrast medium injection was restricted to those frames that had been preceded by at least one normal ventricular contraction.

The following haemodynamic and angiocardiographic parameters were evaluated.

I) End-diastolic volume of left ventricle (LVEDV).
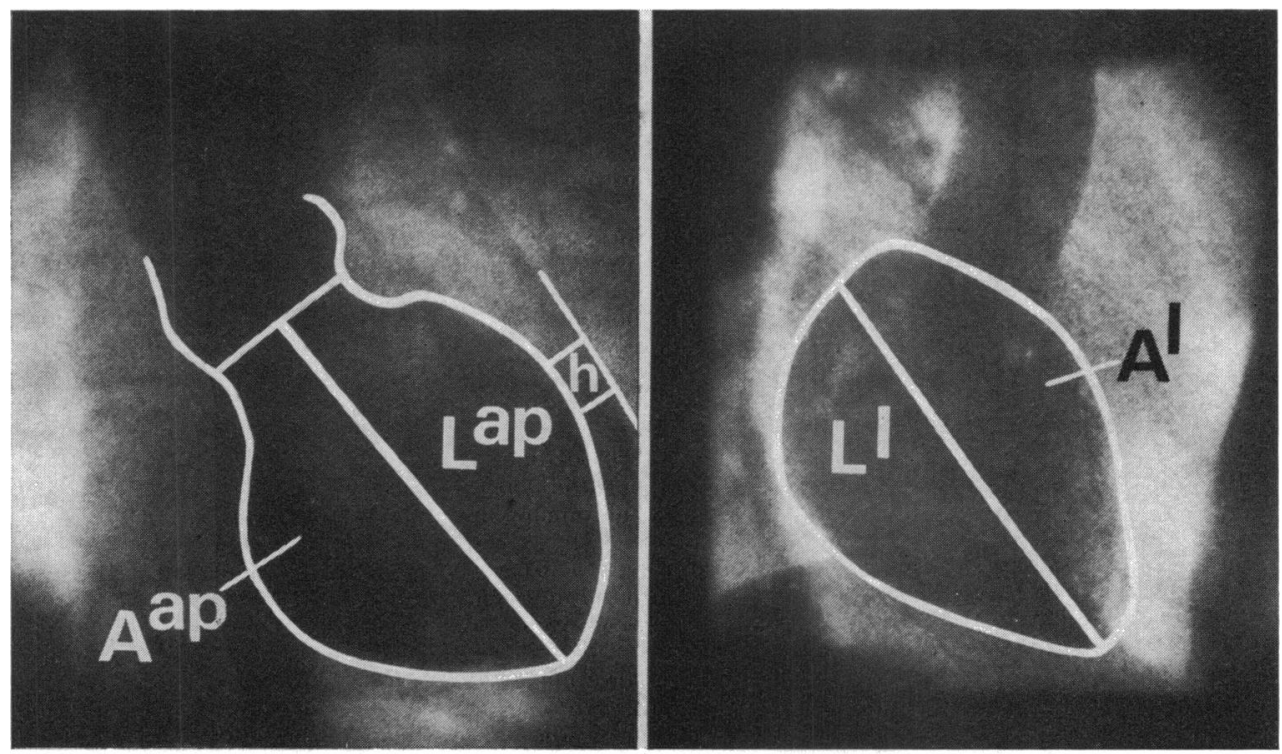

FIG. I End-diastolic biplane angiocardiogram of left ventricle in anteroposterior (left) and lateral (right) projections ( $L=$ long axis, $A=$ projection area, $h=$ wall thickness). 
2) End-systolic volume of left ventricle (LVESV); both LVEDV and LVESV were determined by the 'area length method', described by Dodge and coworkers (1960).

3) Left ventricular stroke volume (LVSV). $L V S V=L V E D V-L V E S V$

4) Left ventricular end-diastolic pressure (LVEDP), measured at beginning of isometric contraction.

5) Left ventricular stroke work index (LVSWI). LVSWI $=0.0136 \cdot($ LVMP - LVEDP) LVSV heart rate (where LVMP is the mean systolic pressure in the left ventricle, measured by planimetry).

6) End-diastolic (circumferential) wall tension of the left ventricle (LVEDT), according to thin-walled ellipsoidal model of Sandler and Dodge (1963).

7) Muscle mass of left ventricle (LVM), estimated by the method of Rackley and co-workers (1964).

8) Work-mass index $=\frac{\text { LVSWI }}{\text { LVM }}$.

9) Tension-mass index $=\frac{\text { LVEDT }}{\text { LVM }}$.

10) Values for volumes and mass of the left ventricle are normalized for body surface area.

Further methodological details have been reported in our earlier publications (Pech and Porstmann, 1968a, b, c; Pech, 1973; Pech et al., 1973).

Correction for $x$-ray magnification and spherical aberration of the electromagnetic lens system was made by the technique of Kasser and Kennedy (1969). After investigation, a brass plate with $\mathrm{I} \mathrm{cm}^{2}$ cross perforations was filmed in the position of the left ventricle and at an equal distance from the image intensifiers. The correction factor was calculated by superimposing the ventricular tracing and the $\mathrm{I} \mathrm{cm}^{2}$ point pattern of perforations.
The actual area $\left(A_{a}\right)$ of the left ventricle was measured by counting the number of $\mathrm{I} \mathrm{cm}$ squares which enclosed the opacified ventricle, and from its ratio to the planimetered area $\left(A_{\mathfrak{p}}\right)$ the linear correction factor $(K)$ was determined in the following way:

$$
\mathrm{K}=\sqrt{\frac{\mathrm{A}_{\mathrm{a}}}{\mathrm{A}_{\mathrm{p}}}}
$$

Each axis of the ventriculogram was corrected by the above factor. Significance was verified by means of the unpaired t-test.

\section{Results}

All values recorded from the 64 patients with and without coronary arteriosclerosis are given in Table I.

In Group I, the left ventricular mass was significantly increased $(t=2.31 ; P<0.05)$, and highly significant increases were recorded from Groups II and III $(t=3.96$ and $t=3.33$ respectively, $P<0.001)$, as compared with the cases without coronary artery disease (Group O) (Fig. 2).

In no group was there a correlation between stroke work index and the mass of the left ventricle, though LVSWI and the index LVSWI/LVM were significantly lower in Group III $(t=3.40$ and $t=3.42$ respectively, $P<0.001$ ) than in the control group (Fig. 3).

In patients with coronary arteriosclerosis enddiastolic tension, pressure, and volume tended to be high, but in all groups there were some patients whose haemodynamic parameters remained normal under resting conditions (Table I). There were

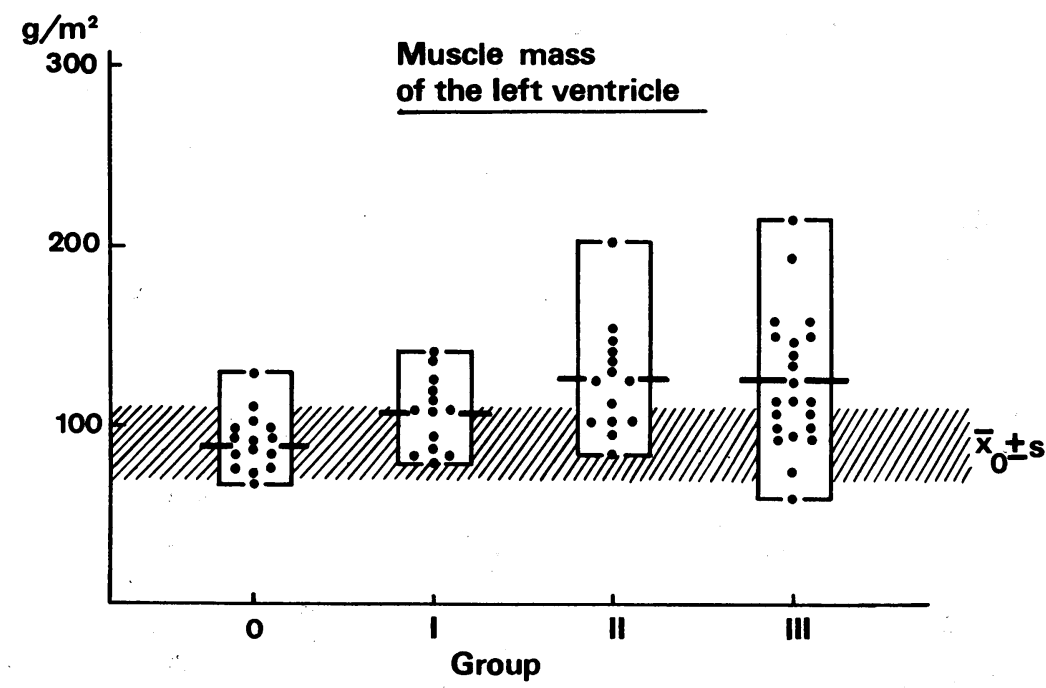

FIG. 2 Mass of left ventricle in four groups of patients with (I, II, III) and without $(O)$ coronary artery disease (hatched area represents mean value of control group \pm standard deviation). 


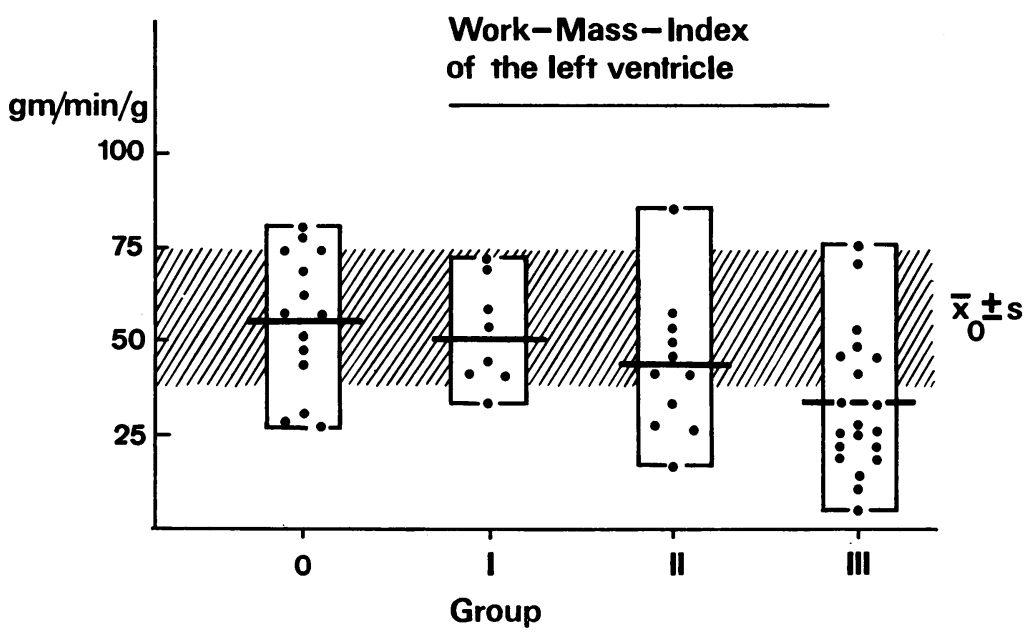

FIG. 3 Work-mass index of left ventricle; Group III differs significantly from control group $(t=3.42 ; P<0.01)$.

significant correlations between the mass of the left ventricle and end-diastolic tension and pressure in Groups II and III, whereas a less significant correlation was found for the end-diastolic volume (Table 2).

There were no significant differences between the groups with regard to the tension-mass index. Values higher than the average of other groups were recorded only from 5 patients with coronary artery occlusion (Fig. 4) $(t=0.44 \mathrm{I}, \mathrm{t}=0.026$, and $\mathrm{t}=2.02$, $P>0.05$, for Groups I, II, and III, respectively).

\section{Discussion}

At the present time, quantitative angiocardiography is generally accepted as the best method for approximate determination of left ventricular muscle mass in vivo. Studies by Kennedy et al. (1967), comparing angiographic with necropsy measurements of left ventricular mass, seem to suggest that fair agreement can be expected as long as the wall thickness, determined at the lateral outline of the heart, is representative of the entire circumference. For this reason, no case with deformation of the ventricular cavity by aneurysm has been included in the scope of this study.

No correlation was found to exist between the estimated mass of the left ventricle and 'external' work (LVSWI). This was expected, since all the patients were normotensive, and there was no significant difference in cardiac output between the groups. Significant reduction in LVSWI in Group III results from a smaller difference between mean and end-diastolic left ventricular pressures.

Some patients with severe coronary arteriosclerosis showed an increase in end-diastolic wall tension; this should be interpreted as compensation by the Frank-Starling mechanism, whereby an adequate cardiac output is maintained by higher wall tension. Increased wall tension is accompanied

TABLE 2 Correlations between left ventricular muscle mass $\left(\mathrm{g} / \mathrm{m}^{2}\right)$ and haemodynamic parameters in patients with coronary heart disease

\begin{tabular}{|c|c|c|c|}
\hline Haemodynamic parameter & $\begin{array}{l}\text { Group } \\
I\end{array}$ & $I I$ & $I I I$ \\
\hline $\begin{array}{l}\text { LV stroke work index }\left(\mathrm{kpm} / \mathrm{min} / \mathrm{m}^{2}\right) \\
\mathrm{LV} \text { end-diastolic tension }(\text { dyne } / \mathrm{cm}) \\
\mathrm{LV} \text { end-diastolic pressure }(\mathrm{mmHg}) \\
\mathrm{LV} \text { end-diastolic volume }\left(\mathrm{ml} / \mathrm{m}^{2}\right)\end{array}$ & $\begin{aligned} r & =0.330^{\star} \\
N & =8 \\
r & =0.309^{\star} \\
N & =10 \\
r & =0.230^{\star} \\
N & =10 \\
r & =0.325^{\star} \\
N & =13\end{aligned}$ & $\begin{aligned} r & =-0.129^{\star} \\
N & =11 \\
r & =0.652 \dagger \\
N & =13 \\
r & =0.646 \dagger \\
N & =13 \\
r & =-0.049^{\star} \\
N & =14\end{aligned}$ & $\begin{aligned} \mathbf{r} & =-0.349^{\star} \\
\mathrm{N} & =20 \\
\mathbf{r} & =0.619 \ddagger \\
\mathrm{N} & =20 \\
\mathbf{r} & =0.664 \ddagger \\
\mathrm{N} & =20 \\
\mathbf{r} & =0.551 \ddagger \\
\mathrm{N} & =22\end{aligned}$ \\
\hline
\end{tabular}

$$
\star \text { = not significant } \quad \dagger=P<0.05 \quad \ddagger=P<0.01 .
$$




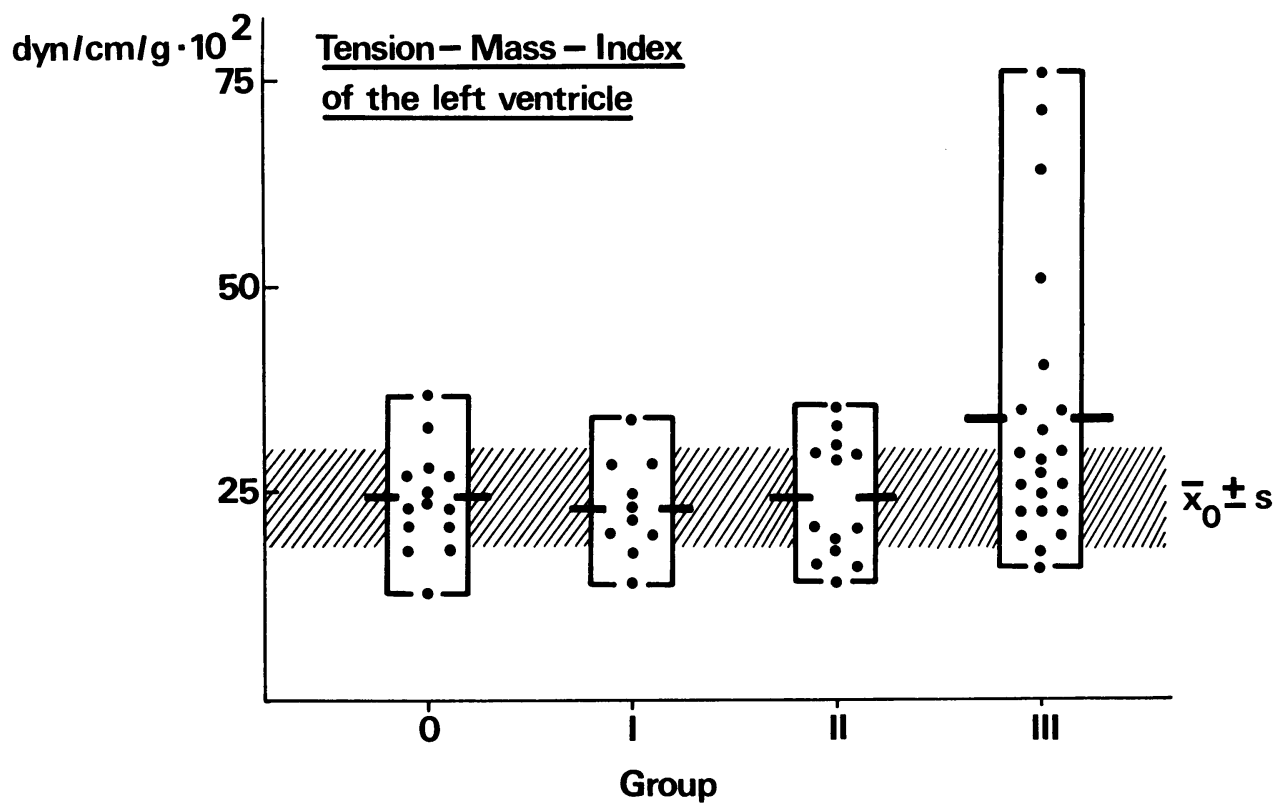

FIG. 4 Tension-mass index of left ventricle; no significant differences between groups (I, II, III) with coronary artery disease and control group $(O)$.

by increasing mass of the left ventricle; however, performance related to mass tends to decline in cases with advanced coronary arteriosclerosis. We can only speculate as to the genesis of the increase in left ventricular weight. Probably this can be attributed to two causes: proliferation of connective tissue due to repair of hypoxic necroses and vicarious hypertrophy of the remaining myocardium (Badeer, 1972; Meerson, 1969). At present there is no method for in vivo differentiation of the connective tissue component from cardiac muscle.

Weight increase accompanied by increased diastolic wall tension, as calculated, seems to suggest an alteration of the contraction mechanism, a phenomenon assumed by Badeer (1971, 1972) to occur with hypertrophy of the heart in the course of chronic ischaemia.

Thus, increase in the weight of the ventricle might be a process which counteracts the high wall tension which usually results from left ventricular dysfunction caused by coronary arteriosclerosis. Such an assumption appears to be supported by our own cases which failed to show any significant change in the tension-mass index.

Necropsy investigations (Adler and Sandritter, 197I; Eisenstein and Wied, 1970) have shown that rising myocardial weight is accompanied by activation of the synthesis of protein and new formation of contractile structures. In acute experiments noninfarcted areas of myocardium have been shown to exhibit the same changes after induced ischaemia (Gudbjarnason, Braasch, and Bing, 1968). Further research, including metabolic studies, will be required to establish whether or not the same process occurs in hypertrophy of the left ventricle caused by chronic ischaemia in man.

\section{References}

Adler, C. P., and Sandritter, W. (I97I). Numerische Hyperplasie der Herzmuskelzellen bei Herzhypertrophie. Deutsche medizinische Wochenschrift, 96, 1895.

Badeer, H. S. (197I). Myocardial blood flow and oxygen uptake in clinical and experimental cardiomegaly. American Heart fournal, 82, I05.

Badeer, H. S. (1972). Pathogenesis of cardiac hypertrophy in coronary atherosclerosis and myocardial infarction. American Heart fournal, 84, 256.

Busch, W. (1953). Die vikariierende Hypertrophie in der linken Herzkammer. Cardiologia, 22, 366.

Dodge, H. T., Sandler, H., Ballew, D. W., and Lord, J. D., Jr. (1960). The use of biplane angiocardiography for the measurement of left ventricular volume in man. American Heart fournal, 60, 762.

Eisenstein, R., and Wied, G. L. (1970). Myocardial DNA and protein in maturing and hypertrophied human hearts. Proceedings of the Society for Experimental Biology and Medicine, 133, 176.

Ellis, L. B., Allison, R. B., Rodriguez, F. L., and Robbins, S. L. (1962). Relation of the degree of coronary artery disease and of myocardial infarctions to cardiac hypertrophy and chronic congestive heart failure. New England fournal of Medicine, 266, 525.

Gudbjarnason, S., Braasch, W., and Bing, R. J. (I968). Protein synthesis in cardiac hypertrophy and heart failure. 
In Heart Failure, Pathophysiological and Clinical Aspects, p. I84. Ed. by H. Reindell, J. Keul, and E. Doll. G. Thieme, Stuttgart.

Herman, M. V., Heinle, R. A., Klein, M. D., and Gorlin, R. (1967). Localized disorders in myocardial contraction: asynergy and its role in congestive heart failure. New England fournal of Medicine, 277, 222.

Judkins, M. P. (1968). Percutaneous transfemoral selective coronary arteriography. Radiologic Clinics of North America, 6, 467.

Kasser, I. S., and Kennedy, J. W. (1969). Measurement of left ventricular volumes in man by single-plane cineangiocardiography. Investigative Radiology, 4, 83.

Kennedy, J. W., Reichenbach, D. D., Baxley, W. A., and Dodge, H. T. (1967). Left ventricular mass. Comparison of angiocardiographic measurements with autopsy weight. American fournal of Cardiology, 19, 221.

McCain, F. H., Kline, E. M., and Gilson, J. S. (1950). A clinical study of $28 \mathrm{I}$ autopsy reports on patients with myocardial infarction. American Heart fournal, 39, 263.

Meerson, F. Z. (1969). The myocardium in hyperfunction, hypertrophy and heart failure. Circulation Research, 24, Suppl. II.

Murata, K., Terasawa, F., Kuramochi, M., Ikeda M., and Seki, M. (1972). The relation of blood pressure and degree of coronary atherosclerosis to myocardial lesions and cardiac hypertrophy. Fapanese Heart fournal, 13, 34.

Pech, H. J. (1973). Quantitative angiocardiography of the normal left ventricle. Cor et Vasa, 15, 101.

Pech, H. J., and Porstmann, W. (I968a). Bestimmung des Schlagvolumens des linken Ventrikels durch Angiokardiographie. Zeitschrift fürKreislaufforschung, 57, 319.
Pech, H. J., and Porstmann, W. (1968b). Näherungsweise intravitale Bestimmung der Muskelmasse des linken Ventrikels. Fortschritte auf dem Gebiete der Röntgenstrahlen und der Nuklearmedizin, 108, 425.

Pech, H. J., and Porstmann, W. (I968c). Zur Bestimmung des enddiastolischen Volumens des linken Ventrikels durch Angiokardiographie. Fortschritte auf dem Gebiete der Röntgenstrahlen und der Nuklearmedizin, 108, 705.

Pech, H. J., Witte, J., Romaniuk, P., Porstmann, W., and Parsi, R. A. (1973). Zu den Beziehungen zwischen Druck, Volumen und Wandspannung des linken Ventrikels und dem koronarographischen Befund bei Patienten mit ischämischer Herzkrankheit. Deutsches Gesundheitswesen, $28,1223$.

Rackley, C. E., Dear, H. D., Baxley, W. A., Jones, W. B., and Dodge, H. T. (1970). Left ventricular chamber volume, mass, and function in severe coronary artery disease. Circulation, 4I, 605.

Rackley, C. E., Dodge, H. T., Coble, Y. D., and Hay, R. E. (1964). A method for determining left ventricular mass in man. Circulation, 29, 666.

Sandler, H., and Dodge, H. T. (1963). Left ventricular tension and stress in man. Circulation Research, 13, 91.

Zaino, E. C., and Tabor, S. H. (1963). Cardiac hypertrophy in acute myocardial infarction. A study based on 100 autopsied cases. Circulation, 28, 1081.

Requests for reprints to Dr. H. J. Pech, I Medical Clinic, Charité Hospital, GDR-IO4 Berlin, Schumannstrasse 20/2I, G.D.R. 